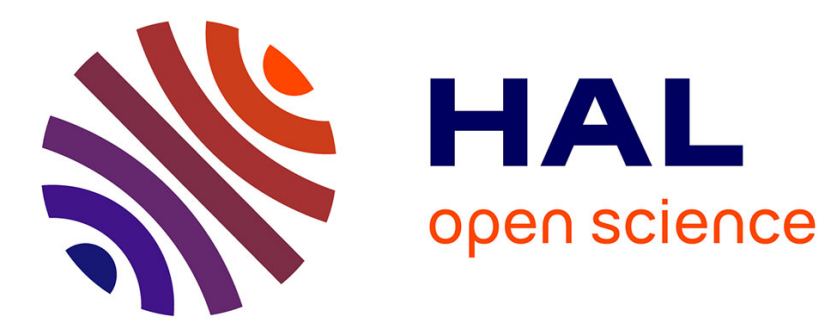

\title{
Si and Si@C Nanoparticles for Lithium-Ion Batteries Anodes: Electrode/Electrolyte Interface Evolution
}

Antoine Desrues, John P. Alper, Florent Boismain, Karim Zaghib, Eric de Vito, Sylvain Franger, M. Trudeau, Cédric Haon, Nathalie Herlin-Boime, H. Demers, et al.

\section{To cite this version:}

Antoine Desrues, John P. Alper, Florent Boismain, Karim Zaghib, Eric de Vito, et al.. Si and Si@C Nanoparticles for Lithium-Ion Batteries Anodes: Electrode/Electrolyte Interface Evolution. 237th ECS Meeting, May 2020, Montréal, Canada. cea-02482651

\section{HAL Id: cea-02482651 https://hal-cea.archives-ouvertes.fr/cea-02482651}

Submitted on 19 Feb 2020

HAL is a multi-disciplinary open access archive for the deposit and dissemination of scientific research documents, whether they are published or not. The documents may come from teaching and research institutions in France or abroad, or from public or private research centers.
L'archive ouverte pluridisciplinaire HAL, est destinée au dépôt et à la diffusion de documents scientifiques de niveau recherche, publiés ou non, émanant des établissements d'enseignement et de recherche français ou étrangers, des laboratoires publics ou privés. 
Click here to print this page now.

You have submitted the following abstract to 237th ECS Meeting with the 18th International Meeting on Chemical Sensors (IMCS 2020) (May 10-15, 2020). Receipt of this notice does not guarantee that your submission was complete, free of errors, or accepted for presentation.

\section{Si and Si@C Nanoparticles for Lithium-Ion Batteries Anodes: Electrode/Electrolyte} Interface Evolution

A. Desues (Université Paris Saclay, IRAMIS, UMR NIMBE, CEA Saclay), J. P. Alper (Université Paris Saclay, IRAMIS, UMR NIMBE, CEA Saclay, Univ. Grenoble Alpes, CEA-LITEN), F. Boismain (Université Paris Saclay, IRAMIS, UMR NIMBE, CEA Saclay), H. Demers, R. Veillette, D. Clément (CETEES HydroQuébec), K. Zaghib (Research Institute of Hydro-Quebec (IREQ)), E. De Vito (Univ. Grenoble Alpes, CEA-LITEN), S. Franger (ICMMO-ERIEE, UMR CNRS-UPS 8182, Université Paris Sud), M. Trudeau (CETEES HydroQuébec), C. Haon (CEA-Liten, 38000, Grenoble, France), and N. Herlin (Université Paris Saclay, IRAMIS, UMR NIMBE, CEA Saclay)

\section{Abstract Text:}

Due to increasing demand in energy storage, much attention has been paid to Si as an anode material in Li-lon batteries because of its theoretical capacity $\left(3579 \mathrm{mAh} / \mathrm{g}\right.$ in the $\mathrm{Li}_{15} \mathrm{Si}_{4}$ alloy vs $372 \mathrm{mAh} / \mathrm{g}$ for graphitic carbon). However, silicon suffers from several drawbacks, including rapid pulverization and SEI ripening, limiting its use. Nanostructuration and protection of silicon with a carbon coating are proven methods to improve the behavior of silicon-based anodes [1]. Using the laser pyrolysis method, the synthesis of silicon-carbon core-shell nanoparticles was achieved in a continuous way, without intermediate manipulations between the synthesis of the core from silane precursor and the shell from ethylene [2].

The influence of the carbon coating on electrochemical performances was studied in coin cells in operando conditions by using electrochemical impedance spectroscopy (EIS) as well as post mortem analysis of the anode by using (X-Ray Photon electron Spectroscopy (XPS), Scanning Electron Microscopy (SEM) and High Resolution Transmission Electron Microscopy (HRTEM)). Special attention was paid to the first cycle because of its major importance in the formation and growth of the SEI and the long term behavior of the battery. By comparing measurements on Si and Si@C materials, EIS clearly demonstrates the beneficial effect of the carbon shell in the SEI stabilization. The stability of the the SEI resistance shows the protective effect of the the carbon shell while the SEI resistance is strongly modified and increases during lithiation. Such behavior can be related to the evolution of the chemical composition determined by XPS at different potentials during lithiation and delithiation.

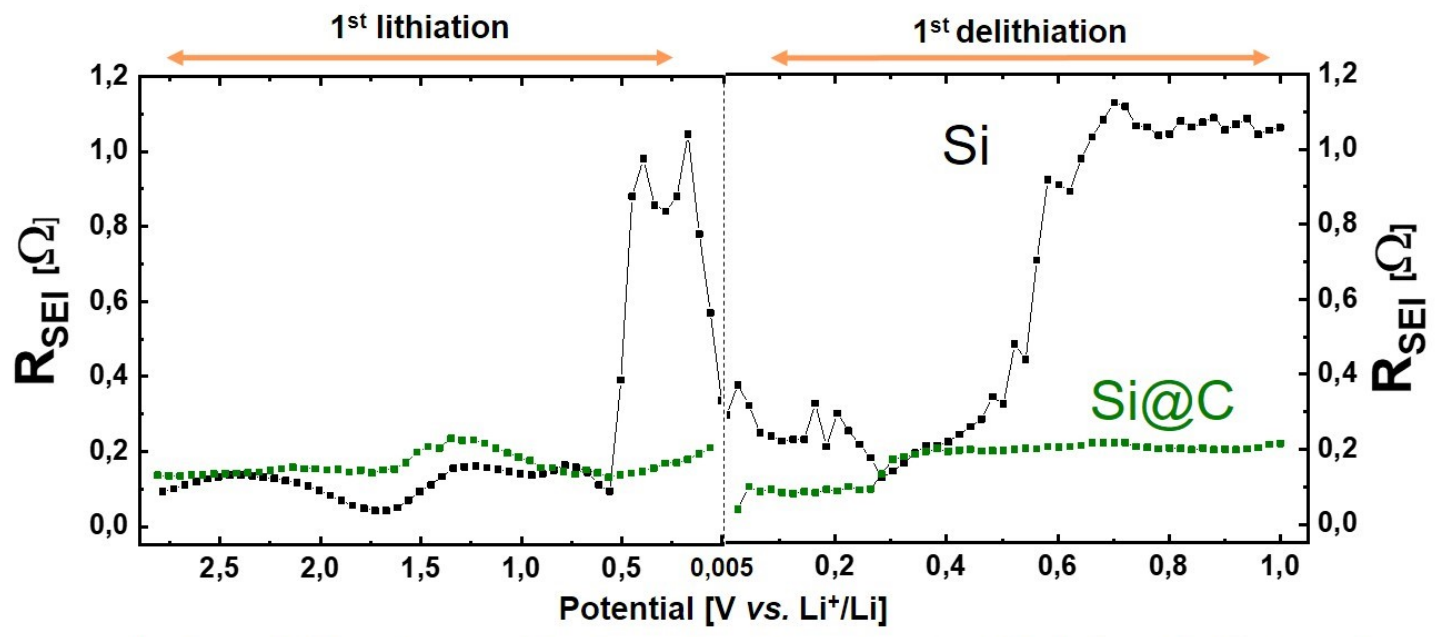

Evolution of SEI resistance $\left(R_{\mathrm{SEI}}\right)$ as a function of potential during the first cycle 